\title{
Jazyk ako básnická téma Bohuslava Tablica Lenka Rišková
}

\author{
RIŠKOVÁ, L.: Language as a Subject in the Poetry of Bohuslav Tablic \\ SLOVENSKÁ LITERATÚRA 67, 2020, No. 3, p. 187 - 203 \\ DOI: https://doi.org/10.31577/slovlit.2020.67.3.1
}

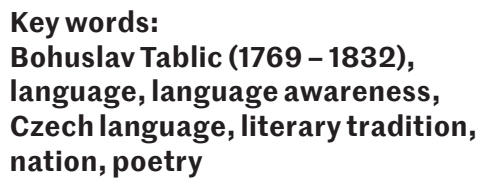

The question of encouraging love for one's own language as an essential identifying sign of a nation is one of the significant subjects in the poetry of Bohuslav Tablic (1769-1832), who did a lot to help stimulate the interest in the original language of the Slovak population as well as in its literary form. Although his literary language is usually superficially described as Czech, it is not accurate as he himself promoted the project of the common literary language for both Slovak and Czech language communities, where Czech and Slovak elements would be applied equally. The choice of his literary language was supported by the three-hundred-year-old tradition of Czech language (also in the Slovak environment), which he regarded as one of the proofs of its full develoment. The analyses of his poetry show that he considered it to be a suitable platform for reflecting on the problems in the society at that time including the issue of language. There are a number of poems in which he appealed to the Slovak society to realize the importance of the language for its life in the multilinguistic Habsburg monarchy. He often called for study of the national language, for its development and refinement mainly through its active use in literary production.

Klúčové slová:

Bohuslav Tablic (1769 - 1832), jazyk, jazykové povedomie, čeština, literárna tradícia, národ, poézia 

máciu o úmrtí Bohuslava Tablica (1769-1832), pripomenul pri tom nielen jeho mnohopočetné a rôznorodé literárne aktivity, ale osobitne upriamil pozornost' na jeho výnimočný vzt'ah $\mathrm{k}$ domácemu jazyku, jeho dôkladnú znalost' a predovšetkým záujem o jeho pestovanie a zdokonal'ovanie: „Veliká stráta potkala nás Slováky a naši literaturu (...) On byl horlivý milovník a zástupce i vzdèlávatel reči slovenské, jejiž gruntovni známostínad mnohé učené pred čil. "1 Palkovičov pojem „řčc slovenská" tu treba chápat vo význame literárneho jazyka, ktorý zastával funkciu aj oficiálneho liturgického jazyka protestantskej časti slovenského jazykového spoločenstva a ktorý sa tradične zvykne zjednodušene označovat' pojmom čeština. Presnejšie však neraz ide o istú podobu česko-slovenského jazyka, teda istú - nie však jednotným, ale skôr rôznorodým spôsobom - modifikovanú podobu slovakizovanej češtiny. ${ }^{2}$ Tablicov výnimočný vztah k domácemu jazyku sa prejavoval nielen v tom, že ho s oblubou používal, čím sa jasne prezentoval ako jeho „horlivý milovník“. Ked'ho J. Palkovič charakterizoval ako „zástupcu ivzdělavatele reči slovenské “, jednoznačne odkazoval aj na d'alšie úrovne jeho vzt'ahu k domácej reči, resp. na zásadné spôsoby jeho angažovania sa pri jej podpore i obrane, a to nielen názormi, ale i činmi (počnúc vlastnou kazatel'skou činnostou až po podporu zakladania katedier česko-slovenského jazyka, najprvv Bratislave a neskôr aj v Banskej Štiavnici). Rovnaké ciele možno identifikovat' i v jeho literárnej tvorbe, ktorou zásadne napomáhal etablovaniu sa tohto jazyka vo všetkých sférach života slovenskej spoločnosti ako podstatnej súčasti multietnického Uhorska či celej habsburskej monarchie. Reflektujúc mnohé iniciatívy smerujúce k obmedzeniu jeho používania aktívne prezentoval svoje postoje k domácemu jazyku, obhajoval potrebu jeho poznania i budovania si pevného vztahu k nemu, ba dokonca nutnosti jeho neustáleho zdokonal'ovania (aj prostredníctvom použitia v literárnej tvorbe). Cielene sledoval i chválil aktivity tých, ktorí si uvedomovali jeho význam pre rozvoj celého národa i krajiny, používali ho, resp. podporovali jeho použivanie. Apeloval na rešpekt voči jazyku a na jazykové právo jeho používatel'ov (či už v spoločenských, ale postupne aj v politických otázkach). V tomto zmysle možno viaceré Tablicove vyjadrenia zacielené na podporu domáceho jazyka, na budovanie vzt'ahu k nemu, ale aj na odsudzovanie akýchkol'vek prejavov nezáujmu oň, jeho bezcitného odmietania či dokonca úmyselného potupovania vnímat' ako jasné signály jeho jazykovo-obranných tendencií, ktoré sa celkom prirodzene prejavili práve $\mathrm{v}$ jeho literárnej tvorbe.

Počiatky formovania Tablicovho jazykového povedomia možno hl'adat' už v jeho študentských časoch. Na pevné základy, ktoré mu vštepil jeho otec

1 PALKOVIČ, Juraj: Literární zprávy. In: Tatranka, roč. 1, 1832, č. 1, s. 114 - 115.

2 Počiatky používania a rozšírenia češtiny v slovenskom prostredí odvodzovali protestantskí vzdelanci z husitskej tradície, ked' sa českí husiti v rámci tzv. husitských vojen dostali až na slovenské územie a údajne tu založili aj svoje dediny. Rovnakú argumentáciu používa aj sám Tablic v básni Světlo literního umění: „V této válce se řeč česká znamenitě po uherské zemi rozšírila." TABLIC, Bohuslav: Světlo literního umění. In: Poezye. Díl první. Vacov, 1806, s. 116. 
pôsobiaci dlhé roky ako učitel', ${ }^{3}$ nadviazal počas štúdií na bratislavskom lýceu v rokoch 1783-1789. Tablic prišiel do Bratislavy v období vel'mi intenzívnych aktivít slovenskej inteligencie za zrovnoprávnenie domáceho jazyka, t. j. jazyka slovenského etnika v mnohonárodnostnom Uhorsku. Bol to čas silnejúcich úsilí o jeho uznanie za jeden z viacerých oficiálnych administratívnych jazykov v rámci Uhorska, čo by malo za následok aj zvýšenie možností na realizovanie spoločensko-politických požiadaviek silnejšie sa presadzujúceho slovenského národa. Tieto aktivity boli prirodzeným dôsledkom osvietenských reforiem realizovaných $\mathrm{v}$ habsburskej monarchii, ked'napríklad v rámci školskej reformy (Ratio educationis, 1777) sa do systému vzdelávania zaradilo aj vyučovanie materinských jazykov jednotlivých jazykových spoločenstiev. ${ }^{4}$ Vel'a o vtedajšom naladení slovenskej spoločnosti vypovedá napríklad známa apológia Jana Hrdličku, uverejnená v Starých novinách literního uměni ${ }^{5} \mathrm{v}$ roku 1785, ktorá vyvolala v slovenskom prostredí vel'ký ohlas Hrdlička v nej obhajoval pozíciu slovanských jazykov medzi ostatnými jazykmi. Možno ju vnímat' ako jeho dôkladne vyargumentovanú obranu pred neprajníkmi, ale aj ako výzvu, aby si príslušníci slovanských národov začali vážit svoje vlastné jazyky a začali sa zaujímat'o ich zdokonal'ovanie, pestovanie a podporovali literárnu tvorbu v nich, ako dôkaz ich životaschopnosti: „O bláze tedy všem nám národi̊m slovenským, že již více mrtvými mezi živými býti nemusite. A proto podte a společně slavnost na památku tohto tak slavného vzkřišseni réči naši sobě zasvětte. "6 J. Hrdlička sa v nej odvážne a sebavedome postavil na odpor všetkým, ktorí by tieto jazyky znevažovali: „Ale čas jest, aby sobě již usmyslili. Nebo co sám král ctí, kdo to ctíti nebude? Co samo v sobě jest vznešené, kdo hoden jest to potupovati? Povinnost raději tu jest každého rozumného, jednomukaždému jazyku čest jeho príti."7

Okrem všeobecnej podpory zvel'ad'ovania a docenenia všetkých slovanských jazykov však práve v čase Tablicových lyceálnych štúdií v Bratislave dosahujú vrchol aktivity slovenskej katolíckej inteligencie o presadenie pôvodného slovenského jazyka, teda jazyka tzv. panónskych Slovákov, čiže Slovákov v Uhorsku (vo význame jazyka použivaného v bežnom hovorenom prejave), do pozície oficiálneho literárneho i administratívneho jazyka. Netajili sa ambíciou očistit' ho od vplyvov češtiny - ako sa píše v Bernolákovej Dizertácii: „Bolo doteraz vrelou a obzvlášt chvályhodnou túžbou vel'mi mnohých milovníkov slovenského jazyka v Uhorsku, aby sa

3 Podla Ruda Brtáňa otec Bohuslava Tablica, Martin Tablic, študoval v rokoch 1759 - 1761 na bratislavskom lýceu a jeho spolužiakmi boli napríklad Ján Chrastina, Martin Klanica, Ján Čerňanský, Ján Szentkereszty z Hontu či Pavel Valaský. Cit. podla BRTÁŇ, Rudo: Bohuslav Tablic (1769-1832). Život a dielo. Bratislava : Veda, 1974, s. 15 -16. „Mali za profesorov slávnych historikov: Jána Tomku Sáskeho, Belovho pokračovatela v Bratislave, a nadovšetko historika Jozefa Bencúra. Preto z ich radov, podnietený aj dobovými tendenciami historickými, aj krajovými historickými (najmä v Gemeri), vyniklo tol'ko bádatel'ov v histórii. Otec Bohuslavov iste upozornil syna i na Jána Chrastinu a jeho veršovnícku zručnost' v kalendároch a mohol mu dat' prvé podnety na historické skúmanie.“ Tamže, s. 16.

4 S upevňovaním názoru, že každý národ má právo na vzdelanie vo svojom vlastnom jazyku, sa postupne začala formovat' aj ich národná kultúra. Bližšie WINTER, Eduard: Josefinismus a jeho dějiny. Praha : Jelínek, 1945; RAPANT, Daniel: K počiatkom mad'arizácie. Diel I. Vývoj rečovej otázky v Uhorsku v rokoch 1740 - 1790. Bratislava : Spisy Filozofickej fakulty Univerzity Komenského, 1927.

5 HRDLIČKA, Jan: Vznešenost řeči české neb vůbec slovenské. In: Staré noviny literního umění, 1785, s. 417 - 438. Cit. podl'a KRAUS, Cyril: Kritika v slovenskom národnom obrodení. Bratislava : Veda, 1990, s. $30-36$.

6 Tamže, s. 30.

7 Tamže, s. 36. 
v takomto vel'kom množstve mužov vel'mi zbehlých vo všetkých náukach našiel niekto, kto by, odložiac na nejaký čas dôležitejšie a vedeckejšie práce, obrátil pozornost'a svoj učený záujem na vypracovanie pravopisu a výslovnosti panónsko-slovenskej a na ich očistenie od chýb prenesených do nášho jazyka z výslovnosti a pravopisu českého." ${ }^{8} \mathrm{~V}$ týchto slovách sa odzrkadluje zásadný problém slovenskej spoločnosti, ktorým bolo rozdielne nazeranie na podobu oficiálneho literárneho jazyka Slovákov. Anton Bernolák nimi jednak potvrdzuje dlhodobejšie snahy v slovenskom prostredí o zvel'adenie slovenského jazyka, no zároveň jasne upozorňuje na to, že sa to neraz dialo na úkor jeho čistoty, ked'ho mnohí literárne aktívni učenci „obohatili aj o poučky a učebnice zamerané skôr na jeho uhladenie, no natol'ko ich preplnili poučkami, čerpanými z prameňov českého jazyka, že boli viac prispôsobenépouživaniu Čechov ako panónskych Slovákov. "9

Na druhej strane, práve blízkost'a živý kontakt s vyspelou českou literárnou tradíciou (aj vd'aka jazykovému úzu v liturgii) boli rozhodujúcim elementom a nosným motívom úvah všetkých zástancov češtiny v pozícii literárneho jazyka v slovenskom prostredí, predovšetkým však z radov protestantskej inteligencie. ${ }^{10}$ Ich základným argumentom bola bohatá historická i literárna tradícia češtiny, ktorá dokonca prevyšovala tradíciu nemčiny. Slovami Pavla Tešláka: „Toho času zajisté, když česká řečjiž vyzdobena byla, Němci ještě ani o vyopraveni své reči nesmýšleli. A kdy Čechové hromadně historické, právní, lékařské a duchovní knihy v pěkné češtině skládli, Němci ještě o učených věcech v svém jazyku ani mluviti nesmèli. "11 To sa napokon stalo aj základným východiskom každej obhajoby práva češtiny na zrovnoprávnenie s ostatnými jazykmi.

Rozvíjanie pozitívneho vzt'ahu k vlastnému jazyku (či už češtiny ako literárneho jazyka alebo pôvodného jazyka uhorských Slovákov) spoločne s rozširovaním možností jeho kultivácie a s upevňovaním jeho pozície $\mathrm{v}$ literárnom i mimoliterárnom prostredí sa zároveň začalo vnímat ako klúčový prostriedok zušlachtovania a napokon i demonštrácie kultúrnej vyspelosti všetkých jeho nositel'ov, teda celého národa. Potvrdzuje to aj vyjadrenie Pavla Tešláka: „Kdyby se lidu našemu způsob ukázal, kterak by snadně známosti svého jazyka nabýti mohli, za to mám, že by se mnohem větším počtem o to pričinili, aby zpưsobnějšimi a umělejšími Slováky býti mohli. "12 Nezáujem o vlastný jazyk či dokonca jeho znevažovanie bolo čoraz intenzívnejšie vnímané i prezentované ako prejav nízkeho sebavedomia hodný opovrhnutia, ako je zrejmé zase zo slov Juraja Ribaya:

„Každý národ jazyka svého tak jest milovný, že jej nejen možnou přičinlivostí, pilností a ustavičným cvičením učiti se vynasnažuje, ale i jiným národům a cizozemcům v známost uvésti usiluje. Sama slovenská nacie jakousi zvláštní odbojností

8 BERNOLÁK, Anton: Praefatio. In: Dissertatio phiolologico-critica de literii slavorum... Posonii, 1787, s. III - XIV. Cit. podla Kraus, c. d., s. 36- 37.

9 Tamže, s. 37.

10 HUČKO, Ján: Sociálne zloženie a pôvod slovenskej inteligencie v prvej fáze národného obrodenia. In: K počiatkom slovenského národného obrodenia. Zborník štúdii Historického ústavu SAV pri príležitosti 200-ročného jubilea narodenia Antona Bernoláka. Bratislava : Vydavatel'stvo SAV, 1964, s. 31 - 54.

11 Z korešpondencie Juraja Ribaya s Pavlom Tešlákom - zo súboru dvanástich listov s názvom Georgii Ribay prima exertitia ortographie Bohemicae Jenae 1781 sub Pauli Tesslák, ktorých rukopis je uložený v Országos Széchényi Könyvtár v Budapešti, pod sign. Quart. Slov. 2. nro. 1. Cit. podla Kraus, c. d., s. 17. 12 Tamže, s. 16. 

zuje. Odtud'pochází, že mnozí nášs slovenský jazyk potupuji a jej docela zanedbávají, a tím větši rozkoš a oblíbení v cizich mají, a s nimi se úsilně obírají a všecken čas na ně vynakládají. Ještě jini takovou nevážnost naproti slovenčině prokazují, že se za ni jako za nějakou zámořskou a divočinou zapáchajicí řeč stydi." 13

Dôležitou osobnostou, ktorá práve v čase lyceálnych štúdií ovplyvnila mladého B. Tablica v rôznych oblastiach, nevynímajúc otázku záujmu o domáci jazyk a jeho pestovania či zdokonal'ovania, bol Michal Institoris Mošovský (1732 - 1803), bratislavský evanjelický kazatel', osvietenský spisovatel', zberatel' a vydavatel' kníh v bibličtine, profesor mravnej teológie a homiletiky, a predovšetkým jedna z rozhodujúcich osobností bratislavského kultúrneho prostredia. ${ }^{14}$ Vo vzdelaneckých kruhoch bol uznávaný nielen ako morálna a teologická autorita, ale aj ako pevný a zásadný zástanca češtiny vo funkcii literárneho jazyka Slovákov. Vd'aka Mošovskému a jeho bohatej knižnici sa slovenskí študenti (a to nielen z evanjelického lýcea, ale tiež z katolíckeho generálneho seminára) mali možnost' zoznámit' s českými gramatikami Vavrinca Benedikta Nedožerského (1603) a Václava Rosu (1672), či s novšou gramatikou Pavla Doležala (1746), spoznat' staršiu i novšiu literárnu produkciu českej a slovenskej proveniencie, a zároveň oboznámit' sa s českou súdobou tlačou, ${ }^{15}$ aj s informáciami o nových (najmä jazykovo-obranných) ideách, rezonujúcich v českom prostredí, ktoré boli pre slovenské prostredie v mnohom inšpirujúce. O tom, aký vel'ký vplyv mal Mošovský na mladého študenta B. Tablica, svedčia Tablicove neskoršie dedikácie: okrem toho, že mu zložil vel'kú poklonu v príležitostnej básni Na smrt Michala Institorisa Mošovského, ${ }^{16}$ jeho pomerne obsiahly portrét ponúkol vo svojej literárnohistorickej reflexii slovenských, resp. v slovenskom prostredí pôsobiacich evanjelických básnikov Paměti česko-slovenských básnírưv aneb veršovcưv (v ich tret'om zväzku vydanom v roku 1809), ${ }^{17}$ kde okrem iného napísal: ,o rozšiřrení a zvelebeníc čsko-slovenskéliteratury horlivě pracoval, byv své mateřské reči velikým milovníkem. "18 Vd'aka Mošovskému - pre jeho literárnu a editorskú činnost' - sa tak Tablic mohol už ako mladý dostat' k celkom praktickým aktivitám smerujúcim k zásadným otázkam podoby, kvality, ale aj spôsobov kultivácie domáceho jazyka (literárneho jazyka), no predovšetkým k úvahám o jeho úlohe a význame pre život celého slovenského jazykového spoločenstva.

13 Tamže, s. 15 - 16.

14 KOWALSKÁ, Eva: Michal Institoris Mošovský a jeho miesto v evanjelickej a. v. komunite v 18. storočí (Pokus o portrét osobnosti). In: KOWALSKÁ, Eva: Evanjelické a. v. spoločenstvo v 18. storočí. Hlavné problémy jeho vývoja a fungovania v spoločnosti. Bratislava : Veda, 2001, s. 141 - 165.

15 Brtáň, c. d., s. 23.

16 TABLIC, Bohuslav: Na smrt Michala Institorisa Mošovského. In: Poezye. Díl čtvrtý. Vacov, 1812, s. 84-90.

17 TABLIC, Bohuslav: Paměti československých básnírúv aneb veršovcův... In: Poezye. Díl třetí. Vacov, 1809 , s. 54- 63.

18 Tamže, s. 55 - 56. Zoznam dielv domácom jazyku, ktoré Mošovský zredigoval, preložil i sám napísal, resp. pričinil sa o ich vydanie a doplnil ich svojimi komentármi, predhovormi či poznámkami, začína Tablic tiež neprehliadnutelným konštatovaním: ,i sám, jak v latinském a uherském, tak obzvláště v mateřském svém, sobě mezi všemi nejmilejším, jazyku knihy pilně vydával, i jiným učeným Slovákům k vydání kněh, kteréž sepsali, všelijak napomáhal.“ Tamže, s. 56. 
Ked'že Tablicov pobyt na bratislavskom evanjelickom lýceu sa súbežne prekrýval aj s aktivitami slovenských katolíckych vzdelancov z bratislavského generálneho seminára, celkom prirodzene aj on sám sledoval a autenticky evidoval ich iniciatívy (odvíjajúce sa od zámeru kodifikácie samostatného slovenského jazyka). Ako príslušník evanjelickej konfesie pridŕžajúci sa tradície češtiny (hoci v rôznej miere slovakizovanej) vo funkcii oficiálneho literárneho jazyka v slovenskom prostredí celkom prirodzene odmietal ich odtrhnutie sa od spoločnej česko-slovenskej tradície. Napriek tomu mu evidentne konvenoval ich záujem o pôvodný domáci - teda slovenský - jazyk. Sám totiž vyzýval slovenských vzdelancov, aby zbierali a zaznamenávali pôvodné slovenské slová: „dobrá slovenská, Čechưm neznámá a v slovárích se nenacházejíci slova."19 Domáce (teda slovenské) jazykové prvky chcel implementovat' do základnej kostry českého jazyka: čeština mala tvorit' gramatickú základňu a slovenčina mala obohatit' tento jazyk po lexikálnej stránke, pretože bol presvedčený, že v slovenčine sa zachovalo ovel'a viac pôvodných slovanských reliktov, ktoré už v živej češtine zanikli, resp. boli vytlačené vplyvom iných jazykov, predovšetkým nemčiny. ${ }^{20}$ Jedine tak sa podla neho podarí pôvodný domáci jazyk zachovat' $\mathrm{v}$ jeho autentickej podobe. ${ }^{21}$

Tablicovou túžbou evidentne bolo vytvorit' spoločný jazyk pre obe národné spoločenstvá, hlavným argumentom tejto požiadavky bola dlhoročná spoločná literárna tradícia: „Česi s uherskými Slováky jedno a tož písmo majíce, společnou snažnostíod starodávna literatúru znova zvelebovali a až podnes zvelebovati maji. “22 Žial', táto predstava nenašla výraznejšiu odozvu v českom prostredí. ${ }^{23} \mathrm{~V}$ každom prípade však Tablicova predstava o podobe domáceho literárneho jazyka, apriórne ovplyvnená ideou spoločného jazyka pre obe národné spoločenstvá - teda pre Slovákov i Čechov, nie je totožná s dlhodobo preživajúcimi literárnohistorickými závermi, ktoré všeobecne charakterizujú jazyk slovenských evanjelických autorov

19 TABLIC, Bohuslav: Paměti československých básnírúv aneb veršovcův... In: Poezye. Díl čtvrtý. Vacov, 1812, s. LXIII.

20 Tablic označoval jazyk, v ktorom písal, nie iba ako český jazyk, ale systematicky používal zložený výraz československý, resp. česko-slovenský jazyk. Na jednej strane by bolo možné tento výraz tradične vnímat ako identický s výrazom čeština; zložený výraz mohol totiž podla dobového úzu označovat' príslušnost' jazyka k slovanskému prostrediu, pričom prefix česko- presne špecifikoval, že išlo o slovanské územie obývané českým obyvatel'stvom. Na druhej strane ale mohlo dôjst' aj k istému posunu a v Tablicovom prípade je táto možnost'ovela viac pravdepodobná: celkom zámerne mohol používat výraz pozostávajúci $\mathrm{z}$ dvoch rovnocenných častí, v ktorom prvá čast' slova česko- označuje príslušnost' k českému prostrediu a jeho druhá čast' -slovenský zase príslušnost' už ku konkrétnemu slovenskému (teda nie všeobecne slovanskému) prostrediu. Takýto výklad je totiž celkom kompatibilný s Tablicovou často prezentovanou predstavou o spoločnom jazyku dvoch jazykových a národných spoločenstiev, českého a slovenského.

21 Preto aj kládol vel'ký dôraz na spoznávanie a zachovávanie starých literárnych pamiatok: „Mámet', díka Bohu, ještě některé pozústalé smutného rumu ostatky, a nechceme-li se předků našich konečně nehodni státi, tedy sbírati tito zříceniny a nové stavení, pokud možné, vzdělati musíme." TABLIC, Bohuslav: Pár slov k Čechům, Moravanům a Slovákům spolu so sprievodným listom J. Nejedlému zo dňa 23. 3. 1803. LA PNP v Prahe, sign. 22 R 76.

22 Tablic, Poezye. Díl první, c. d., s. 110. K tomuto problému sa Tablic vyjadril aj v d'alšom článku, ktorý bol publikovaný až po jeho smrti. TABLIC, Bohuslav: O literních svazcích Slováku s Čechy a Moravany. In: Časopis českého musea, roč. 16, 1842, s. $579-594$.

23 Ako ukázal nasledujúci vývin, požiadavky obohacovania češtiny o slovenské prvky neboli v českom prostredí vôbec prijaté. „Tablic pak žádá na Češích v zájmu jazykové jednoty určité reformy, nebo spiše modifikace, které sa částečně shodují se snahami českých buditelů, částečně jsou nedůležité, částečně však pozoruhodné (...) Čeští jazykoví zákonodarci neučinili tyto a podobné slovenské náměty ani věcí diskuse.“ ČAPEK, Jan Blahoslav: Československá literatura toleranční I. Praha : Čin, 1933, s. 377. 
unifikujúco a jednoznačne ako češtinu. V dôsledku toho sa vytrvalo prehliadajú

dôležité indície poukazujúce na špecifické a doposial'stále ešte nie celkom preskúmané kritériá týchto autorov na podobu domáceho literárneho jazyka - a to s dôsledným prihliadaním na možné individuálne osobitosti požiadaviek každého z nich.

Rovnako nie je celkom správne interpretované ani Tablicovo gesto odmietnutia bernolákovskej kodifikácie, ktoré sa priam vytrháva z kontextu pri čítaní jeho básne Slávia věncem zdobená. ${ }^{24}$ Konkrétne ide o nasledujúce verše:

„Vy učedlníci Bernolákovi!
Než kdo to vám, co piśi, dopoví?
Preč vrzte psáni způsob smyšlený,
a zvolte od tři set let schválený!
Proč jdete mezi husté bodláčí,
kamž pěkná Slávia jet' neráčí?
Jak naleznout tam vonné květiny,
kde země vyvodí jen trniny?
Zdaž českých jednověrců šlepěje
vás nectí? O, již máme koleje!
Proč v bahně kolej novou šlápáte?
Kyž cestou ustlanou již taháte!
Ach, lép jest hladkou stezkou choditi,
než po rozcestí špatně blouditi!" 25

I napriek prvotnému dojmu odmietnutia či dokonca istého rozhorčenia B. Tablic neznevažuje prácu bernolákovcov nasmerovanú k lepšiemu poznaniu a pozdvihnutiu domáceho jazyka v slovenskom prostredí, teda pôvodného slovenského jazyka, ani nepopiera jeho existenciu, ani ho nijak nedehonestuje. Obrazom, ktorým Tablic pripodobňuje bernolákovské kodifikačné snahy ku kráčaniu po blatistom chodníku plnom tŕnia a bodlačia, vedúcemu k poblúdeniu, len zdôrazňuje, že slovenčina, ktorú si bernolákovci vybrali a rozhodli sa ju postavit' na roveň všetkým ostatným, častokrát vyspelejším a na literárnu tradíciu bohatším jazykom, bude mat' ovel'a t'ažšiu pozíciu. ${ }^{26}$ Uvedomoval si totiž, že ide o jazyk bez literárnej tradície - na rozdiel od češtiny s rozsiahlou literárnou produkciou i viacerými gramatickými príručkami, ktoré jej automaticky zaručujú isté renomé a lepšiu východiskovú situáciu. Bernolákovský projekt teda Tablic odmietal nie preto, že by neuznával kvality (a vôbec existenciu) domáceho slovenského jazyka. Jeho odmietnutie ich riešenia jazykovej otázky v slovenskom prostredí a rozhodnutie sa pre češtinu možno skôr vnímat' ako pragmatické rozhodnutie sa pre istým spôsobom jednoduchšiu cestu. Spojenie s bohatšou a vyspelejšou českou tradíciou

\footnotetext{
24 TABLIC, Bohuslav: Slávia věncem zdobená. In: Poezye. Díl čtvrtý, c. d., s. 13 - 27.

25 Tamže, s. 26-27.

26 Tablic si volí tento motív zrejme celkom zámerne a možno ho vnímat ako priamu reakciu na Bernoláka, ktorý topos protikladu novej verzus starej, už vyšliapanej cesty použil vo svojej Disertácii - a to v dvoch mottách k nej. Prvé motto bol citát od Senecu: „Prečo teda nepôjdem v šlapajách predchodcov? Budem zaiste použivat starú cestu, ale ak nájdem kratšiu a priamejšiu, vybudujem ju. Pravda je všetkým na dosah, ešte nie je vyčerpaná: mnoho z nej zostalo tiež pre potomkov.“ Druhý citát bol z Tacita: „Tí, ktorí idú priamymi a primeranejšími cestami, prinášajú viac úžitku. “Cit. podla Kraus, c. d., s. 247, 248.
} 
vnímal ako prostriedok jednoduchšieho presadenia sa aj Slovákov v rámci Uhorska a zároveň aj za základný impulz ich formujúceho sa národného sebavedomia. ${ }^{27}$

Aj tento nenápadný, no o to viac vypovedajúci moment potvrdzuje, že Tablic intenzívne povzbudzoval a podporoval všetky aktivity (teda aj Bernolákove), ktorých ciel'om bolo pestovanie domáceho jazyka a jeho postupné etablovanie vo všetkých sférach spoločenského života. Ďalším z dôkazov sú napríklad slová uznania, ktoré adresoval svojmu vzácnemu mecénovi Jurajovi Zmeškalovi:

„Nad to pak nadevšecko Vaše vys. uroz. milost (...) naší pak slovenskou řeč nejen $v$ soukromnich, ale i veřejných stoličných shromážděnich proti jejím odpưrcưm chvalitebně zastávati ráč́, začež každý dobrého vlasti žádostivý krajan Vaší vys. uroz. milosti v srdci svém tuze zavázan zůstává." 28

Evidentne si uvedomoval náročnost' i historický význam uplatnenia domácej reči vo všetkých sférach spoločenského života (predovšetkým, no nielen vo funkcii literárneho jazyka) a zároveň aj vel'kú zodpovednost' voči nej i celému jazykovému spoločenstvu. Tieto ciele prenikli naprieč všetkými Tablicovými aktivitami, ktorým sa počas svojho života venoval. Napríklad inicioval vznik inštitúcií na pestovanie jazyka: podporoval vznik Katedry reči a literatúry československej na bratislavskom lýceu, priamo sa angažoval pri zakladaní rovnakej katedry na lýceu v Banskej Štiavnici, na jeho podnet vznikla knižnica pri tejto katedre. Okrem toho pripravoval plán vybudovania celoslovenskej učenej spoločnosti, ktorá by popri ostatných vedných odboroch zastrešovala aj výskum jazyka. (To sa mu síce nepodarilo zrealizovat' spoločne s bratislavskou katedrou, no neskôr si tieto túžby aspoň čiastočne kompenzoval pri založení Učenej spoločnosti banského okolia v roku 1810.) Edične pripravil na vydanie výber z pôvodnej slovenskej literárnej tvorby. No a v neposlednom rade, vedomie zodpovednosti za domáci jazyk, jeho rozvoj, kultiváciu i budovanie vztahu domáceho obyvatel'stva k nemu, jednoznačne zanechali citel'nú stopu aj v jeho vlastnej literárnej tvorbe. Prostredníctvom literárnohistorickej reflexie starších slovenských autorov, resp. zo slovenského prostredia pochádzajúcich či v slovenskom prostredí žijúcich a tvoriacich autorov (známej pod skráteným názvom Paměti), ${ }^{29}$ chcel dokumentovat' kontinuitu jazykového i kultúrneho povedomia slovenského jazykového spoločenstva, a tak zároveň medzi jeho členmi oživit' vedomie domácej literárnej tradície a inšpirovat' $k$ jej d'alšiemu zvel'ad'ovaniu. ${ }^{30} \mathrm{~S}$ rovnakým ciel'om pristupoval aj k vlastnej básnickej tvorbe, čo potvrdzujú napríklad slová, ktorými komentoval vydanie svojej básnickej zbierky Poezye (vyšla v štyroch zväzkoch v roku 1806, 1807, 1809 a 1812) v predhovore k druhému zväzku: „Mně dosti kvelikému potěšení to poslouži,

27 Viac o Tablicovom postoji voči bernolákovcom RIŠKOVÁ, Lenka: Niekol'ko poznámok o vztahu Bohuslava Tablica k bernolákovcom. In: Slovenská literatúra, roč. 56, 2009, č. 1, s. 1 - 14.

28 TABLIC, Bohuslav: Venovanie. In: Poezye. Díl třetí, c. d., nepag.

29 Paměti československých básníruov aneb veršovcův, kteriž se bud'to v uherské zemi narodili aneb aspoň v Uhřích živí byli Paměti vychádzali ako súčast štyroch zväzkov básnickej zbierky Poezye v rokoch 1806, 1807, 1809 a 1812.

30 V úvodnom predhovore k prvému zväzku Pamětí napríklad napísal: „Když pak sem k této práci přistupoval, tedy přirozená věc byla na to pomysleti, co již vedle v předešlých časých od našich Slováků v poetském umění učiněno jest.“ TABLIC, Bohuslav: Předmluva. In: Poezye. Díl první, c. d., nepag. 
jestli i vydáním těchto básni zarostlá cesta česko-slovenské literaturyv naši milé Slávii poněkud se proklestí a přimějši učini, a láska k naší výborné otcovské réeči a literatuře v srdci mnohého studeného Slováka obžive."31 (zvýr. L. R.)

Vysokú mieru zaangažovanosti mladého básnika v jazykovej otázke, resp. v otázke podpory a povznesenia domáceho jazyka dokumentuje jeho azda najznámejšia báseň s názvom Svobodné volení, ktorú v plnom zmysle možno označit' za jeho programovú. ${ }^{32} \mathrm{~V}$ záverečnej časti, ktorou vrcholí básnikov výpočet toho, čo by chcel v živote dosiahnut', sa objavuje dnes takmer až notoricky známa pasáž, kde si žiada knižnicu so vzácnymi knihami slávnych autorov z Anglicka, Francúzska, Nemecka, Talianska, Ruska, i Pol'ska a Čiech. Tradične sa tento obraz zvykne interpretovat' ako jednoznačný dôkaz Tablicovho osvietenského myslenia a prejav jeho obdivuhodnej vzdelanosti a rozhl'adenosti. $V$ tieni tejto prvoplánovej interpretačnej roviny však zostávajú nasledujúce slová, v ktorých básnik priamo vyjadruje svoju túžbu podla príkladu všetkých významných osobností uvedených v menoslove vydávat' rovnaké knihy aj v domácom jazyku. Tým jasne deklaruje svoj zámer prispiet' podporou literárnej tvorby v tomto jazyku i vlastnou literárnou aktivitou k tomu, aby sa domáca literatúra svojou kvalitou vyrovnala ostatným, už vyspelejším literatúram s bohatšou tradíciou, a v súčinnosti s tým, aby sa povzniesol, zdokonalil a zušlachtil aj domáci jazyk, resp. aby sa tým potvrdili jeho kvality:

„Přátel mých a péč má ta by hlavní byla,
by se slovenská réč zdarně velebila,
vydávali bychom spisy znamenité,
zpěvy, básně krásné, milé, rozmanité,
přijemné by u nás múzy bydlo měli,
slovenské by v Uhřich pisně libě pěli.
Brzy bychom měli juvenále české,
Goldšmidovy zpěvy premilostné hezké,
Miltonové vážní, líbí Horácové,
zpívali by u nás snad i Virgílové.
My bychom je všecky věnci bobkovými
hrdě ozdobili, honosíc se jími.
Apol by hral u nás na citaře sladce,
slovenská by byla požehnaná práce,
jazyk náš by nabyl v premileném květě
slávy, kteráž by se rozmáhala v světě. “33

Ďalšou Tablicovou básňou, v ktorej rezonuje obhajoba domáceho jazyka a priamy apel na jeho používatel'ov, aby si uvedomili potrebu, ba priam nutnost' jeho aktívneho použivania vo všetkých oblastiach života či potrebu jeho pestovania a kultivovania prostredníctvom kvalitnej literárnej činnosti, je báseň známa pod názvom Světlo literního umění, napísaná pri príležitosti založenia Katedry reči a literatúry československej na bratislavskom lýceu a menovania Tablicovho

31 TABLIC, Bohuslav: Předmluva. In: Poezye. Díl druhý, c. d., nepag.

32 TABLIC, Bohuslav: Svobodné volení. In: Poezye. Díl první, c. d., s. 3 - 14.

33 Tamže, s. $13-14$. 

prehl'ade dejín vzdelanosti v slovenskom prostredí, ktoré možno vnímat' ako básnikovo argumentum jeho nasledujúcich viac či menej priamo formulovaných požiadaviek, končí báseň oslavou novozriadenej inštitúcie, do ktorej vkladali vel'ké nádeje všetci protestantskí vzdelanci zo slovenského prostredia. Stala sa akýmsi symbolom ich jazykovo-obranných aktivít za etablovanie českého (resp. československého) jazyka do pozície oficiálneho reprezentanta slovenského jazykového spoločenstva a tiež za zrovnoprávnenie slovanských jazykov s ostatnými jazykmi používanými v monarchii. Založenie katedry a smelé plány o jej činnosti boli v tom čase vnímané ako dôležitý dôkaz životaschopnosti príslušníkov celého slovanského spoločenstva v Uhorsku: „ujala se ratolestka zdarná, / radůjte se, Slavinini synové, / snažnost vaše nezůstane marná, / věnce se vám víti mají bobkové. “35 Vznik katedry považoval B. Tablic za prirodzený dôsledok dlhoročných aktivít a úsilí všetkých domácich vzdelancov, ktoré potvrdzovali predovšetkým vysoký potenciál slovenského a vôbec slovanského obyvatel'stva pre celú monarchiu-vysvetluje to vo svojom komentári k básni, ktorý má (pre Tablica príznačnú) podobu poznámky pod čiarou. Pre správnu interpretáciu jeho slov treba zdôraznit', že práve vysoký pomer slovanského obyvatel'stva v celej monarchii považoval básnik za relevantný dôvod uznania a etablovania slovanských jazykov do tých najvyšších sfér kultúrneho a spoločenského života:

„Již dávno žádali učení a dobrého vlasti žádostiví muži, aby iv Uhrích učitelská stolice řeči a literatury slovenské založena byla, kteráž jejich žádost tím byla slušnější, čím rozšírenější jest řeč slovenská v rakouské monarchii, v kteréžto se près 14 millionů Slovanů, nad nímiž di̊m rakouský štastně panuje, nacházi (...) - odkud i veliká potřeba známosti réci slovenské pro zemského pána, učitele církevniho, prokurátora, lekaře, a vi̊bec pro každého v císařských zemích bydlícího zřetedlnè se poznati dá."36

34 Celý názov básne s jej dedikáciou je Světlo literního umění, kteréž Panonii v rozličných časích svěcovalo a ještě osvěcuje. Zpěv na památku založení professorství řeči a literatury slovenské v Prešpurce a dosednutí na učitelskou stolici vys. učen. muže pana Jiřího Palkoviče L. P. 1803. dne 12. Listop. Tablic, Poezye. Díl první, c. d., s. $109-128$.

35 Tamže, s. 127.

36 Tamže, poznámka pod čiarou s označením cc. Výraz „slovenská“ tu pritom treba interpretovat'vel'mi citlivo vzhl'adom na kontext, v ktorom je použitý, pretože má viac významov: všeobecne môže označovat' príslušnost' k slovanskému prostrediu (v zmysle územia, na ktorom sa používal niektorý zo slovanských jazykov), ale aj celkom konkrétne k slovenskému prostrediu (teda k územiu, na ktorom žilo slovenské obyvatel'stvo a domácim jazykom na ňom bola slovenčina). V citáte je použitý v oboch významoch. Motív rozširenosti slovanských jazykov, resp. početnosti slovanského obyvatel'stva bol tradičným argumentom potvrdzujúcim oprávnenost' jazykovo- i národno-obranných požiadaviek príslušníkov jednotlivých slovanských národov za ich zrovnoprávnenie s ostatnými jazykmi a národmi. Napríklad Jan Hrdlička (vo svojej už vyššie spomínanej obrane) píše: „Má-li tedy řeč naše vzněšenější býti, musí ona vznešenost svou i jiným něčím podpírati. A podporu tuto já dále nacházím na její rozšířenosti. (...) Byt' by ona jedné jediné toliko krajině byla vlastní, jako francouzská Francouzské, vlaská Vlaské, španielská Španielské a uherská Uherské zemi; však již proto vznešenost svou dosti by zastávala. Čím tedy ona vzněšenější býti musí, když ona až po mnohých krajinách se rozlévá. Projdi zajistě, kdo jen chceš, všecky ty krajiny, které od moře poledního až k půlnočnímu leží, nenalizneš-li v nich všudy Slovákư. “ HRDLIČKA, Jan: Vznešenost řeči české neb vůbec slovenské. In: Staré noviny literního umění, 1785, s. 417-438. Cit. podla Kraus, c. d., s. 31. Podobný argument použil aj Anton Bernolák v predhovore k svojej gramatike, pričom v poznámke b) sa odvoláva na presné zdroje týchto názorov. BERNOLÁK, Anton: Praefatio. In: Gramatica slavica. Posonii, 1790, s. III - XVI. Cit. podl'a Kraus, c. d., s. 40-41. 
Aj samotnému Palkovičovi prisudzuje Tablic dôležitú úlohu pri zdoko-

nal'ovaní domáceho jazyka - svojou svedomitou činnost'ou na katedre, teda dôsledným štúdiom a kvalitným vyučovaním domáceho jazyka má napomôct' nielen slovenskému jazykovému spoločenstvu, ale všetkým slovanským národom, aby sa im priznala hodnota medzi ostatnými národmi v monarchii i za jej hranicami:
„A ty, Palkoviči přehorlivý,
Slavinina okraso a radosti!
Vlast jenž drahou zblažit žádostivý
setřels' hořké slzy jeji žalosti,
zveleb slavně Slavinino jméno,
vznes je k oblaků až černých výsostem!“37

Študentom z katedry sa B. Tablic zase osobitne prihovára v inej básni (už spomínanej v súvislosti s bernolákovcami), s názvom Slávia věncem zdobená. ${ }^{38}$ Pred záverečným príhovorom $\mathrm{k}$ bernolákovcom sa totiž nachádza ešte jedna priama apelácia, adresovaná práve študentom - básnik sa v nej netají vel'kými nádejami, ktoré do nich vkladá:

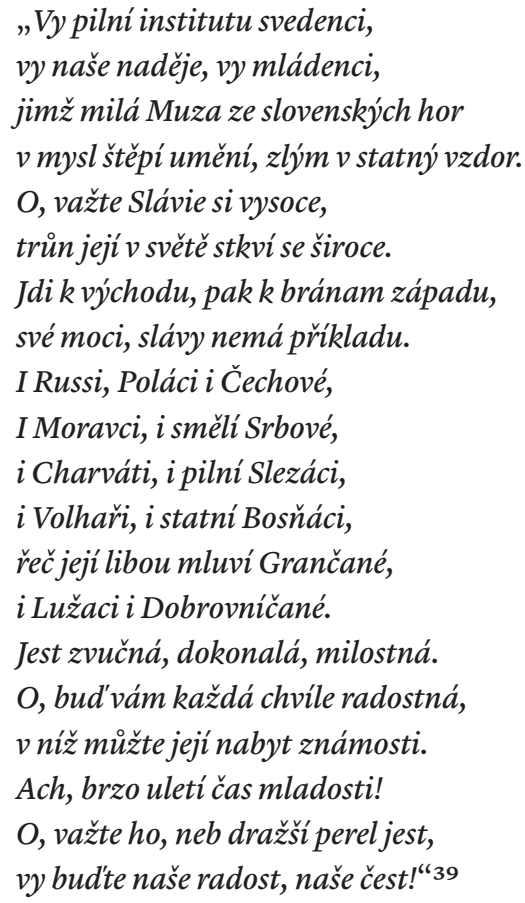

Tablicov príhovor má charakter nielen oslavy domáceho jazyka, ktorý má oporu vo vel'kom slovanskom jazykovom spoločenstve, zároveň je aj prenikavou výzvou k budovaniu pevného vztahu jeho používatel'ov k nemu. V slovách „O, važte 
198 ho, neb dražši perel jest! " 40 prízvukuje študentom, aby si uvedomili význam jazyka pre život celého slovenského spoločenstva ako samostatného národa, pretože jazyk je jedným z najhlavnejších dôkazov jeho existencie. Na motiváciu ponúka príklady ostatných slovanských národov - ako si udržiavajú a pestujú svoj jazyk Rusi, Poliaci, Česi a iné slovanské národy (nie iba v rozmanitej literárnej tvorbe, ale aj v iných oblastiach). Nasledujúc tieto príklady majú si aj Slováci vážit' svoj jazyk.

K zdravo sebavedomému postoju slovenského obyvatel'stva k vlastnému hovorovému, ale predovšetkým $\mathrm{k}$ literárnemu jazyku má podla B. Tablica napomôct' práve činnost' mladých študentov z novozaloženej katedry. Podnecuje ich preto k aktivite a povzbudzuje, aby sa neobávali rôznych prejavov pohŕdania či výsmechu od iných národov, ale aby posilnení ideami svojho profesora (tie sú tu zhmotnené názvom jeho básnickej zbierky Muza ze slovenských hor) ${ }^{41}$ pevne odolávali nepriazňam, vytrvali vo svojej láske k rodnému jazyku a v pevnom vztahu k svojmu pôvodu. Relevantnost' tohto sebavedomia odvodzuje opätovne od významu Slávie ako spoločenstva slovanských národov, teda od vel'kosti, resp. rozšírenosti či početnosti slovanského spoločenstva, ale aj od jeho dôležitého postavenia v rámci celej monarchie či dokonca Európy. V tejto pasáži preto znovu rezonuje Tablicov atak na posilnenie vedomia slovanskej spolupatričnosti, resp. vedomia príslušnosti k vel'kému a významnému spoločenstvu, ktoré je navyše charakteristické rôznorodostou potvrdzujúcou bohatý potenciál. Daný aspekt bol totiž jedným z hlavných argumentov a predovšetkým univerzálnym oprávnením akejkolvek obhajoby jazykovo-obranných úsilí jednotlivých slovanských národov, teda aj slovenského, a rovnako aj aktivít nasmerovaných na upevňovanie jazykového povedomia slovenského obyvatel'stva. Toto všetko formuluje Tablic vel'mi jednoducho, no o to viac dôraznejšie priamou výzvou: „O, važte Slávie si vysoce, / trůn její v světě stkví se široce. "42 Vzbudzovanie pozitívneho vztahu, ba až úcty čitatel'a i celého slovenského obyvatel'stva k vlastnému jazyku možno tak považovat' za jeden zo základných znakov (nielen) Tablicových jazykovo-obranne motivovaných úvah, ktoré prenikli aj do jeho básnického prejavu.

Ďalším z tradičných motívov pri takto formulovaných dielach býva vyratúvanie pozitív domácej reči - tu si vybral Tablic nasledujúce charakteristiky: „Jest zvučná, dokonalá, milostná.“43 Odvoláva sa teda predovšetkým na zvukové kvality, resp. zvukomalebnost' či l'ubozvučnost', ktorá je slovanským jazykom patrične priznávaná a aj všeobecne uznávaná príslušníkmi ostatných jazykových spoločenstiev. ${ }^{44}$ Tablicov výber atribútov zrejme nie je celkom náhodný, práve nimi totiž najvýstižnejšie argumentuje vhodnost' česko-slovenského jazyka (ako oficiálneho literárneho jazyka v slovenskom prostredí) najmä pre literárnu tvorbu. Študentov katedry preto naliehavo vyzýva, aby si uvedomili tieto kvality

40 Tamže.

41 PALKOVIČ, Juraj: Muza ze slovenských hor. Vacov, 1801.

42 TABLIC, Bohuslav: Slávia věncem zdobená. In: Poezye. Díl čtvrtý, c. d, s. 26.

43 Tamže.

44 Rovnaký dôkaz kvality slovanských jazykov spomína aj Bernolák, ked'sa o reči Slovanov vyjadruje ako o vel'mi bohatej a lahodnej: ,tak vyniká, že ozdobnost' všetkých európskych rečí nielenže môže dostihnút', ale dokonca i predčit.“" Dokonca sa priamo odvoláva na vyjadrenie Mateja Bela o tom, že „nezaostáva za pôvabom a hladkostou francúzštiny “. BERNOLÁK, Anton: Praefatio. In: Gramatica slavica. Posonii, 1790, s. III - XVI. Cit. podl'a Kraus, c. d., s. 41. 
a aj vo svojom vlastnom literárnom prejave využili daný potenciál ako najlepšie východisko pri zvyšovaní kreditu nielen svojej vlastnej tvorby, ale všeobecne pri zušlachtovaní a zviditelňnovaní kultúry celého slovenského spoločenstva. Vkladá do nich o to väčšiu nádej, že ich vodcom či sprievodom pri poznávaní kvalít jazyka má byt' práve literárne, no v tomto kontexte predovšetkým básnicky skúsený J. Palkovič, ktorý im má doslova do „myslí vštepit"“ najlepšie základy literárneho umenia, ktorých znalost' potvrdil v najvyššej možnej miere práve svojou básnickou zbierkou - vôbec prvou svojho druhu v dejinách slovenskej literatúry.

V samotnom závere Tablicovho príhovoru k študentom z bratislavskej katedry zaznieva ešte jedna výzva, a to, aby sa naplno venovali štúdiu a zdokonal'ovaniu jazyka, kým sú ešte mladí. Táto výzva sa však nevztahuje výlučne na mladíkov, ale možno ju interpretovat' ako básnickú synekdochu, ako všeobecnú výzvu, básnikovo volanie po akútnom zásahu či bezodkladnom, priam urgentnom aktivizovaní sa celého slovenského spoločenstva, na nutnost' konat' tu a teraz, kým je ešte čas, ak si chce zachovat' svoj jazyk a s ním i svoju identitu, svoju čest', a tak aj zabezpečit' svoju budúcnost'. Do záverečných veršov tak básnik vložil (bezpochyby osobne zainteresovaný) odkaz celému slovenskému jazykovému spoločenstvu: „O, bud'vám každá chvíle radostná, / v niž můžte její nabyt známosti. / Ach, brzo uletí čas mladosti! / O, važte ho, neb dražši perel jest, / vy bud'te naše radost, naše čest!" 45

Identifikovanie takéhoto rozmeru citovaných veršov následne naznačuje, že okrem pozitívnych udalostí smerujúcich $\mathrm{k}$ zdokonaleniu a zrovnoprávneniu domáceho jazyka reflektoval Tablic vo svojich básňach aj problémy, ktoré tento proces komplikovali. Dosvedčujú to básne, v ktorých možno sledovat' identický zámer - pričom ciel'om básnika nie je poukázat' na problémy len v jemných náznakoch, ale aj celkom konkrétne. Ide predovšetkým o problém odmietania rodného jazyka príslušníkmi slovenského národa a uprednostňovanie cudzích jazykov, či dokonca problém odnárodňovania slovenskej inteligencie. Prvému sa venuje v príležitostnej básni Du. p. Janovi Seberínimu, ${ }^{46}$ ktorému vyčíta, že svoju učeb$n^{n i c u}{ }^{47}$ napísal v latinčine a nie v domácom jazyku:

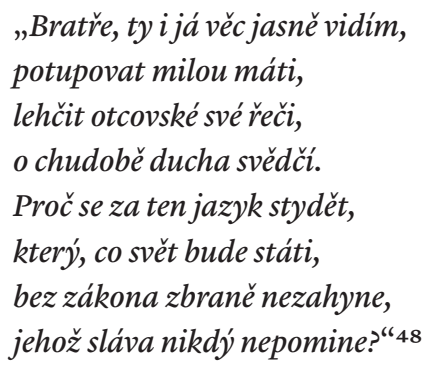

Druhému problému sa venuje (a to vel'mi pôsobivo) najmä v baladicky ladenej básni Vilím Kostka, nevděčný syn. ${ }^{49}$ Ponúka v nej tragický príbeh o synovi

46 TABLIC, Bohuslav: Du. p. Janovi Seberínimu. In: Poezye. Díl čtvrtý, c. d., s. 45 - 52.

47 Ide o učebnicu pedagogiky, resp. príručku pre pedagógov a vychovávatel'ov s názvom De praecipuis capitibus primae Educationis z roku 1810.

48 TABLIC, Bohuslav: Du. p. Janovi Seberínimu. In: Poezye. Díl čtvrtý, c. d., s. 50.

49 TABLIC, Bohuslav: Vilím Kostka, nevděčný syn. In: Poezye. Díl třetí, c. d., s. 134-143. 
200 slovenskej matky, ktorý po odstahovaní sa do mesta a zabezpečení si vysokého spoločenského postavenia nielenže odmieta používat' svoj rodný jazyk vo verejnom aj v osobnom živote, ale dokonca zapiera svoj slovenský pôvod a spolu s ním i vlastnú matku - ked' ho príde navštívit', vyženie ju zo svojho domu. Matka následne po vel'kom sklamaní zo syna umiera v samote. Báseň končí Tablicovou prísnou výčitkou voči takýmto zradcom, ktorí vidiac len vlastný prospech dokážu zapriet' samých seba, teda to, čo im je dané ako ich sebaurčujúci prvok. Takouto zradou svojho pôvodu potupujú aj svojich najbližších, ba dokonca ich tým dokážu celkom zničit:

„Nejste-li vy nevděčnici, $v y$, jenž jazyk hanite otcovský, vy potupnici toho, čehožnevite?

Slováci vám zniku dali, Slovenky vás zrodily, ony, jichž ste prsy sáli, v chodidlách vás vodily.

Předc svi̊j národ zrazujete, tupice réc slovenskou, nesmyslně zhašujete čitedlnost vlastenskou.

Ach, již slyšset drahé vlasti prežalostný pláče hlas, hled'te, aby hroznou strasti neumřela v krátký čas. “50

Bohuslav Tablic si evidentne uvedomoval nebezpečenstvo zániku celého národa, ktoré mu hrozilo pre odmietanie vlastného jazyka, resp. obmedzenia, ba až celkové minimalizovanie jeho používania, s následným zabudnutím. Preto vel'mi tvrdo odsudzoval všetkých, ktorí zapreli svoj pôvod - okrem iného aj tým, že odmietli či znevažovali vlastný jazyk. Nepretržite apeloval, aby si uvedomovali význam jazyka pre život celého spoločenstva, aby si oživovali vlastný záujem oň a zároveň povzbudzovali aj ostatných $\mathrm{k}$ upevňovaniu svojho vztahu k nemu.

V načrtnutom kontexte Tablicových názorov na domáci jazyk, ktoré prenikli aj do jeho básnickej tvorby, tak vel'mi silno rezonujú i jeho záverečné verše už spomínanej básne venovanej Jánovi Seberínimu ${ }^{51}$ - možno ich charakterizovat' nielen ako lútostivú výčitku, ale zároveň ako zanietené aktivizujúce napomenutie, ba dokonca ako burcujúcu hrozbu, nasmerovanú k všetkým príslušníkom slovenského spoločenstva, aby sa spamätali a začali si vážit' svoj jazyk i pôvod, a uvedomili si tak svoju zodpovednost' za celé spoločenstvo, za svoj národ. Vyzýva

51 TABLIC, Bohuslav: Du. P. Janovi Seberínimu. In: Poezye. Díl čtvrtý, c. d., s. 45 - 52. 
ich, aby svoj vztáah k nemu dokazovali a rozvijali aj v každodennom živote a neustále si uvedomovali a pripomínali jeho kvality a hodnotu. Inak im nezostáva nič iné, len podvolit sa spravodlivým následkom nezáujmu, neochoty a istej obmedzenosti pohl'adu na podstatné veci v živote či nemúdrosti v smerovaní svojho vlastného života:

„Nebe, rač nás uchovati
toho bezectného bludu!
Jináč-nechcem-li se retovati-
podrobmež se, nešt́astníci, soudu
př́sné nebes spravedlnosti!
Shoŕme s dílem nemoudrosti.
Nuže, mluvmež, pišme spilnou péčí
ksvému slovenskému rodu
v milé Slavinině řeči,
již nám láska sladkých matek
kzachování odevzdala,
nám ji brousit přikázala.
Nezlehčujmež mateřského plodu,
zdržujme nám odkázanýstatek.
Libeznátě, zvučná, přemilená,
hojně krásou ozdobená,
vzdělejmež ji s bedlivostí,
oheň lásky, horlivosti
rozžíhejme v srdci Slavinině,
uvozujme její schopné syny
do svatyně Minervině,
všudy znějte jejich statné činy,
moudrosti jim světiž jasné světlo,
aby štěstí Panonie zkvetlo!”52

Tieto slová sú priamym apelom básnika nasmerovaným k všetkým príslušníkom slovenského jazykového spoločenstva, aby sa zaktivizovali, aby si budovali zdravé sebavedomie, a predovšetkým aby si neustále pripomínali zodpovednost' voči tomu, čo je ich vlastnou hodnotou a čo sú povinní odovzdávat' d'alším pokoleniam. Dosvedčujú tak, že Bohuslav Tablic sa intenzívne zaujímal o problémy slovenského jazykového spoločenstva. Otázka významu a hodnoty domáceho jazyka či otázka potreby jeho kultivácie, zdokonal'ovania a predovšetkým praktického používania (napríklad, no nielen) v literárnej tvorbe je jednou z dôležitých a určite neprehliadnutel'ných tém aj jeho básnickej tvorby.

Už samotné rozhodnutie sa pre písanie poézie v domácom jazyku (presnejšie v oficiálnom literárnom jazyku evanjelickej časti slovenského jazykového spoločenstva, ktorým bola nie celkom jednotne slovakizovaná čeština) je prejavom Tablicovho výrazného angažovania sa v tejto otázke. Kedžze básnický prejav 
202 považoval pre náročnost' i schopnost' pôsobit' na city čitatel'a za najvznešenejší (a teda aj za najvhodnejší na sprostredkúvanie vznešených myšlienok a ciel'ov), tvorbou básní v tomto jazyku podáva presvedčivý dôkaz o kvalite domáceho jazyka. Vydanie štyroch zväzkov básnickej zbierky Poezye možno preto vnímat' jednak ako Tablicovu priamu demonštráciu vrúcneho vztahu k domácemu jazyku, ale súčasne ako vel'avravné gesto výraznej podpory i cieleného úsilia o jeho zušlachtovanie a zvyšovania jeho kreditu medzi ostatnými jazykmi. V niektorých Tablicových básňach ale prenikajú tieto intencie aj priamo na povrch v podobe výrazne aktualizovanej prezentácie básnikovho vlastného postoja k jazyku ako k najdôležitejšiemu reprezentantovi kultúrnej vyspelosti jeho používatel'ov. Možno ich interpretovat' ako autentické, hlboko zanietené a vel'mi osobné apely adresované všetkým členom slovenského jazykového spoločenstva, reflektujúce celkom konkrétne problémy súdobej spoločnosti. Ich analýzy potvrdzujú, že nie sú len oslavou jazyka, ale viaceré z nich sú aj presne cielenou kritikou - či už konkrétnych ludí, alebo problémov týkajúcich sa celého slovenského jazykového spoločenstva, ba dokonca niekedy aj s presahom na celé slovanské spoločenstvo. Roznecovanie lásky $\mathrm{k}$ vlastnému jazyku ako podstatnému identifikačnému znaku slovenského národa $\mathrm{v}$ podmienkach multietnického štátneho zriadenia habsburskej monarchie, priame výzvy k tomu, aby si jeho používatelia uvedomili jeho význam pre svoj vlastný život, jasné náznaky odsúdenia tých, ktorí tento jazyk vedome potupujú a tiež autorove básnické obrany pred takýmito útokmi sú bezpochyby vedomým a presne cieleným zámerom Tablicovej poézie.

Štúdia je výstupom grantového projektu VEGA 2/0117/17 Príležitostná básnická tvorba Juraja Palkoviča, Bohuslava Tablica a Pavla Jozefa Šafárika. Zodpovedná riešitel'ka: Mgr. Lenka Rišková, PhD. Doba riešenia: $2017-2020$.

\section{Archivne pramene}

Szechényiho národná knižnica v Budapešti: korešpondencia Juraja Ribaya s Pavlom Tešlákom (súbor dvanástich listov) Georgii Ribay prima exertitia ortographie Bohemicae Jenae 1781 sub Pauli Tesslák. Sign. Quart. Slov. 2. nro. 1.

Literární archiv Památníku národního písemnictví Praha: TABLIC, Bohuslav: Pár slow k Čechům, Morawanům a Slowákům spolu so sprievodným listom J. Nejedlému zo dňa 23. marca 1803. Sign. 22 R 76.

\section{Pramene}

BERNOLÁK, Anton: Praefatio. In: Dissertatio phiolologico-critica de literii slavorum... Posonii, 1787, s. III - XIV.

BERNOLÁK, Anton: Praefatio. In: Gramatica slavica. Posonii, 1790, s. III - XVI.

HRDLIČKA, Jan: Vznešenost řeči české neb vůbec slovenské. In: Staré noviny literního umèní, 1785, s. $417-438$.

PALKOVIČ, Juraj: Literární zprávy. In: Tatranka, roč. 1, 1832, č. 1, s. $114-115$.

TABLIC, Bohuslav: O literních svazcích Slováku s Čechy a Moravany. In: Časopis českého musea, roč. 16, 1842, s. 579 - 594.

TABLIC, Bohuslav: Poezye. Díl první. Vacov, 1806.

TABLIC, Bohuslav: Poezye. Díl druhý. Vacov, 1807. 


\section{Literatúra}

BRTÁŇ, Rudo: Bohuslav Tablic (1769-1832). Život a dielo. Bratislava : Veda, 1974.

ČAPEK, Jan Blahoslav: Československá literatura toleranční I. Praha : Čin, 1933.

HAMADA, Milan - NOVACKÁ, Mária: Úvod. In: K dejinám školstva, vzdelania a kultúry v dobe osvietenskej. Bratislava : Slovenská pedagogická knižnica a Ústav školských informácií, 1987, s. 3 - 8.

HUČKO, Ján: Sociálne zloženie a pôvod slovenskej inteligencie v prvej fáze národného obrodenia. In: K počiatkom slovenského národného obrodenia. Zborník štúdii Historického ústavu SAV pri príležitosti 200-ročného jubilea narodenia Antona Bernoláka. Bratislava : Vydavatel'stvo SAV, 1964, s. 31 - 54.

KOWALSKÁ, Eva: Michal Institoris Mošovský a jeho miesto v evanjelickej a. v. komunite v 18. storoči (Pokus o portrét osobnosti). In: KOWALSKÁ, Eva: Evanjelickéa. v. spoločenstvo v 18. storočí. Hlavné problémy jeho vývoja a fungovania v spoločnosti. Bratislava : Veda, 2001.

KRAUS, Cyril: Kritika v slovenskom národnom obrodení. Bratislava : Veda, 1990.

RAPANT, Daniel: K počiatkom mad'arizácie. Diel I. Vývoj rečovej otázky vUhorsku v rokoch 1740-1790. Bratislava: Spisy Filozofickej fakulty Univerzity Komenského, 1927.

RIŠKOVÁ, Lenka: Niekol'ko poznámok o vztahu Bohuslava Tablica k bernolákovcom. In: Slovenská literatúra, roč. 56, 2009, č. 1, s. 1-14. WINTER, Eduard: Josefinismus a jeho dějiny. Praha : Jelínek, 1945.

Mgr. Lenka Rišková, PhD.

Ústav slovenskej literatúry SAV

Dúbravská cesta 9

84104 Bratislava

Slovenská republika

E-mail: lenka.riskova@gmail.com 